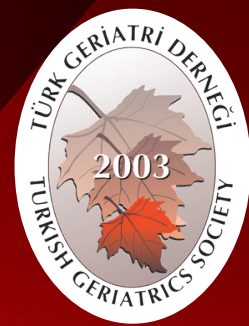

Turkish Journal of Geriatrics DOI: $10.31086 /$ tigeri.2018.54 2018;21 (4):498-506

- Halil Ibrahim ERDOĞDU

- Binali ÇATAK ${ }^{2}$

CORRESPONDANCE

Halil lbrahim ERDOĞDU

Kafkas University, Faculty of Medicine

Department of Internal Medicine, Kars, Turkey

Phone: 04742124207

e-mail: halil-dr@hotmail.com

Received: 29/08/2018

Accepted: 11/12/2018

Kafkas University, Faculty of Medicine, Department of Internal Medicine, Kars, Turkey Kafkas University, Faculty of Medicine, Department of Public Health, Kars, Turkey

\section{INFLUENZA, PNEUMOCOCCAL AND HERPES ZOSTER VACCINATION RATES AMONGST PEOPLE AGED 65 YEARS AND OLDER AND RELATED FACTORS}

\section{Abstract}

Introduction: We determined influenza, pneumococcal and herpes zoster vaccination rates amongst people aged $\geq 65$ years and evaluated factors affecting the vaccination rates.

Materials and Method: The vaccination rates were investigated using face-to-face interview in 543 patients aged $\geq 65$ years who were admitted to the internal medicine outpatient clinics of Kafkas University School of Medicine and public hospitals in the 30th health service area. Subjects were divided into two groups: vaccinated and unvaccinated. Vaccination status was the dependent variable; knowledge of vaccination and socioeconomic and sociodemographic characteristics were the independent variables.

Results: The number of unvaccinated subjects was 6.6 times higher amongst participants with no knowledge of vaccination than amongst those with knowledge of vaccination ( $95 \%$ confidence interval, 2.9-14.9, $\mathrm{p}=0.001), 2.6$ times higher amongst participants with no primary education than amongst those with primary education (confidence interval, 1.5-4.5, $p=0.001$ ), 2.7 times higher in participants with insufficient income than amongst those with sufficient income (confidence interval, $1.2-5.9, \mathrm{p}=0.006$ ) and 2.2 times higher amongst participants living in rural areas than amongst those living in urban areas (confidence interval, 1.2-3.7, p=0.006). These were the factors affecting the vaccination status in the elderly.

Conclusion: Additional solutions are required to encourage physicians and other healthcare providers to provide the elderly with information and encourage them to be vaccinated as recommended by the 'Centre for Disease Control and Prevention', increasing the vaccination rates amongst those living in villages and rural areas and with low income.

Keywords: Aged; Influenza vaccines; Pneumococcal vaccines; Herpes Zoster vaccine

ARAŞTIRMA

\section{ALTMIŞ BEŞ YAŞ VE ÜZERI KIŞiLERIN INFLUENZA, PNÖMOKOK VE HERPES ZOSTER AŞILARINI YAPTIRMA DÜZEYI VE ILIŞKILI FAKTÖRLER}

Öz

Giriş: Bu araştırmada 65 yaş ve üzeri kişilerde influenza, pnömokok ve herpes zoster aşılarını yaptırma düzeyi ile bu düzeyi etkileyen faktörlerin belirlenmesi amaçlanmıştır.

Gereç ve Yöntem: Araştırmanın verileri Kafkas Üniversitesi Tıp Fakültesi ve kamu hastaneleri iç hastalıkları polikliniğine başvuran 65 ve üzeri yaş 543 kişi ile yüz yüze görüşme tekniği ile toplandı. Kişiler aşı yaptıranlar ve yaptırmayanlar olarak iki guruba ayrıldı. Aşılanma durumu araştırmanın bağımlı değişkeni iken, aşı bilgisi, sosyoekonomik ve sosyodemografik özellikler ise bağımsız değişkenleri olarak belirlendi.

Bulgular: Aşı bilgisi olanlar referans alındığında olmayanlarda $6.6(\mathrm{Cl}, 2.9-14.9 ; \mathrm{p}=0.001)$, temel eğitimi olanlar referans alındığında olmayanlarda $2.6(\mathrm{Cl}, 1.5-4.5 ; \mathrm{p}=0.001)$, gelir düzeyi yeterli olanlar referans alındığında yetersiz olanlarda $2.7(\mathrm{Cl}, 1.2-5.9 ; \mathrm{p}=0.006)$, il ve ilçe merkezinde yaşayanlar referans alındığında köy ve beldelerde yaşayanlarda aşılanmama 2.2 kere $(\mathrm{Cl}, 1.2-3.7 ; \mathrm{p}=0.006)$ daha yüksek olup yaşılıarda aşılanmayı etkileyen faktörler olarak belirlendi.

Sonuç: Yaşlı nüfusun "Hastalık Kontrol ve Önleme Merkezi" tarafından önerilen aşıları yaptırmasında hekimlerin aşılar hakkında yaşlıları bilgilendirmesi, köy ve beldelerde yaşayanlar ve gelir düzeyi düşük olanların aşılanma oranlarının arttıııması için doktorlar ve diğer sağlık sunucularının yaşlıları aşılanma konusunda bilgilendirmeleri ve yönlendirmeleri gibi ilave çözümler gerekmektedir.

Anahtar sözcükler: Yaşlı; İnfluenza aşısl; Pnömokok aşısı; Herpes Zoster aşısı 


\section{INTRODUCTION}

Elderly population aged 65 years and older is growing worldwide with increasing average life expectancy. As of 2015, there are 900 million people in the world who are 60 years and older, and it is estimated to reach 2 billion by 2050 (1). According to the Turkish Statistical Institute, the percentage of people aged 65 years and older was $8.5 \%$ in 2017 (2).

Changes occur with ageing in innate and acquired immunities. Thymic involution results in the reduction of the number of T cells and low CD4/ CD8 ratio, affects $B$-cells that provide antibody response, affects dendritic cells responsible for antigen uptake and presentation, decreases the diversity of the $T$ cell repertoire, negatively affects natural killer cells that eliminate infected cells and affects monocytes and macrophages that govern chemotaxis. These changes, termed as 'immunosenescence', increase the risk of exposure to infections in the elderly (3-5).

It is estimated that approximately 3.5 million serious cases of influenza infection are observed every year worldwide, and approximately 250,000 300,000 of these infections are fatal (6). Influenza, which increases and peaks especially in autumn and winter, causes complications and deaths, making the elderly susceptible to pneumococcal infections (7).

Pneumococcal infections occur in a spectrum comprising acute otitis media, sinusitis, meningitis and invasive pneumococcal disease, and the effectiveness of vaccination in protecting against these conditions has been demonstrated (8). If the vaccination status of an elderly patient is unknown or the patient has not been vaccinated, one dose of pneumococcal conjugate vaccine (PCV13) is initially administered followed by one dose of pneumococcal polysaccharide vaccine 23 (PPSV23) after 6-12 months (9); the interval between the two vaccinations should be 2 months at a minimum.
Most people become infected with varicella during childhood, and varicella remains dormant in cranial nerve ganglia. Post-herpetic neuralgia, which is a common complication caused by the spread of the virus to the sensory nerve dermatoma, can be observed in up to $18 \%$ of adults and $33 \%$ of the elderly $(10,11)$. This leads to pain that lasts for months and patients show poor response to analgesics, disrupting their social activity (12).

Owing to these reasons, vaccination strategies for the prevention of diseases, such as influenza, pneumococcal infections, herpes zoster ( $\mathrm{HZ})$, as suggested by the Centre for Disease Control and Prevention (CDC) are important in terms of preventive health services in the elderly (9).

The aim of this study was to determine the level of knowledge of individuals aged 65 years and older on influenza, pneumococcal and $\mathrm{HZ}$ vaccines, and evaluate the factors that may affect vaccination status.

\section{MATERIALS AND METHOD}

The population of this descriptive study comprised individuals aged 65 years and older who were admitted to internal medicine outpatient clinics of Kafkas University School of Medicine and public hospitals located in Kars, Kağızman, Sarıkamış, Ardahan, Göle, Iğdır and Doğubayazit. Approximately 167,760 people aged 18 years and older were admitted to the internal medicine outpatient clinics of these hospitals within 1 year, and the number of patients aged 65 years and older was approximately 33,552 (approximately $20 \%$ of the applicants were 65 years and older). In addition, the average number of repeated admissions to university and public hospitals was 6.6 in the cities where this study was conducted (13). When the number of the elderly admitted to the hospitals (33.552) was divided by the number of repeated admissions (6.6), the population of the study was determined to be approximately 5,089 people. Accordingly, sample size was calculated 
as 537 considering $50 \%$ prevalence rate, $4 \%$ error margin and $95 \% \mathrm{Cl}$.

\section{Data collection form}

The form consisted of questions inquiring sociodemographic and socioeconomic levels of the elderly, information regarding vaccinations and vaccination status.

\section{Data collection}

Data was collected using face-to-face interview. After establishing preliminary diagnosis and planning investigations and treatments on the basis of the reason of admission, participants were taken to a quiet room and the questions were read by the investigator at a sound level wherein his/her voice could be clearly heard by the participants. Verbal answers of the participants who heard and understood the questions were recorded on the forms. Seven people who had communication problems were not included in the study and 27 people did not consent to participate in the study; therefore, the study was completed with 543 participants.

The dependent variable of the study was the vaccination status of the elderly, whereas the independent variables were the socioeconomic and sociodemographic characteristics of the elderly and the level of knowledge on vaccination.

The study protocol was approved by the Clinical Trials Ethics Committee of Kafkas University Faculty of Medicine, Kars, Turkey. The study was conducted in accordance with the declaration of Helsinki, and verbal informed consent was obtained from each patient.

\section{Statistical analysis}

SPSS Statistics of Windows v.21.0 (SPSS; IBM Corporation, New York, USA) was used. Chisquare test was used in the analysis of numeric variables; $p<0.05$ was considered statistically significant. Logistic regression analysis was used for independent variables that were found to be statistically significant in the chi-square test.

\section{RESULTS}

In total, 63 subjects received influenza vaccination only, three received both influenza and pneumococcal vaccinations, one received pneumococcal vaccination and one received all three vaccinations. Consequently, 68 subjects received at least one vaccination.

Table 1 shows the association between influenza, pneumococcal and $\mathrm{HZ}$ vaccination rates and demographic and socioeconomic characteristics, level of knowledge on vaccination and the participants' personal characteristics.

Table 2 shows the percentages of patients who have previously heard of influenza, pneumococcal and $\mathrm{HZ}$ vaccines. The percentages of participants who have heard of these vaccines were $52.7 \%$, $26.9 \%$ and $6.6 \%$, respectively.

Independent variables with statistically significant differences in Table 1 were included in the logistic regression analysis. The following were the parameters affecting the vaccination rate of the participants.

As shown in Table 3, the number of unvaccinated subjects was 6.6 times higher amongst participants with no knowledge of vaccination than amongst those with knowledge on vaccination $(\mathrm{Cl}, 2.9-14.9, \mathrm{p}=0.001), 2.6$ times higher amongst participants with no primary education than amongst those with primary education $(\mathrm{Cl}, 1.5-4.5, \mathrm{p}=0.001), 2.7$ times higher in participants with insufficient income than amongst those with sufficient income $(\mathrm{Cl}, 1.2-5.9, \mathrm{p}=0.006)$ and 2.2 times higher amongst participants living in rural areas than amongst those living in urban areas $(\mathrm{Cl}, 1.2-3.7, \mathrm{p}=0.006)$ (Table 3 ). 
Table 1. The association between influenza, pneumococcal and $\mathrm{HZ}$ vaccination rates and demographic and socioeconomic characteristics, level of knowledge on vaccination and the participants' personal characteristics. (Kars, Turkey; 2017).

\begin{tabular}{|c|c|c|c|c|c|}
\hline \multirow{2}{*}{\multicolumn{2}{|c|}{ Independent Variables }} & \multirow{2}{*}{$\begin{array}{l}{ }^{*} \text { Vaccinated } \\
\text { Number (\%) }\end{array}$} & \multirow{2}{*}{$\begin{array}{r}\text { Unvaccinated } \\
\text { Number (\%) } \\
\end{array}$} & \multirow{2}{*}{$\begin{array}{r}\text { Number } \\
(\%)\end{array}$} & \multirow{2}{*}{$\mathrm{p}$} \\
\hline & & & & & \\
\hline \multirow[t]{2}{*}{ Place of residence } & Village/suburb & $25(8.2)$ & $281(91.8)$ & $306(56.4)$ & \multirow{2}{*}{0.001} \\
\hline & City/town & $43(18.1)$ & 194 (81.9) & $237(43.6)$ & \\
\hline \multirow[t]{2}{*}{ Age } & $65-74$ & $45(13.2)$ & $295(86.8)$ & $340(62.6)$ & \multirow{2}{*}{0.516} \\
\hline & $\geq 75$ & $23(11.3)$ & $180(88.7)$ & $203(37.4)$ & \\
\hline \multirow[t]{2}{*}{ Sex } & Female & $26(9.3)$ & $253(90.7)$ & $279(51.4)$ & \multirow{2}{*}{0.020} \\
\hline & Male & $42(15.9)$ & $222(84.1)$ & $264(48.6)$ & \\
\hline \multirow[t]{2}{*}{ Vaccination information provideda } & Yes & $14(46.7)$ & $16(53.3)$ & $30(5.5)$ & \multirow{2}{*}{0.001} \\
\hline & No & $54(10.5)$ & $459(89.5)$ & $513(94.5)$ & \\
\hline \multirow[t]{2}{*}{ Marital Status } & Widowed & $12(7.8)$ & $142(92.2)$ & $154(28.4)$ & \multirow{2}{*}{0.036} \\
\hline & Married & $56(14.4)$ & $333(85.6)$ & $389(71.6)$ & \\
\hline \multirow[t]{2}{*}{ Elementary school and higher } & No & $29(8.3)$ & $321(91.7)$ & $350(64.5)$ & \multirow{2}{*}{0.001} \\
\hline & Yes & $39(20.2)$ & $154(79.8)$ & $193(35.5)$ & \\
\hline \multirow[t]{2}{*}{ Mode of residence } & Rental & $4(22.2)$ & $14(77.8)$ & $18(3.3)$ & \multirow{2}{*}{0.206} \\
\hline & Family's property & $64(12.2)$ & $461(87.8)$ & $525(96.7)$ & \\
\hline \multirow[t]{2}{*}{ Living with } & Alone & $2(5.9)$ & $32(94.1)$ & $34(6.3)$ & \multirow{2}{*}{0.227} \\
\hline & Spouse/children & $66(13.0)$ & $443(87.0)$ & $509(93.7)$ & \\
\hline \multirow[t]{2}{*}{ Number of people in the family } & $\leq 4$ & $51(14.0)$ & $314(86.0)$ & $365(67.2)$ & \multirow{2}{*}{0.144} \\
\hline & $>4$ & $17(9.6)$ & $161(90.4)$ & $178(32.8)$ & \\
\hline \multirow[t]{2}{*}{ Health insurance } & Green card & $12(7.3)$ & $153(92.7)$ & $165(30.4)$ & \multirow{2}{*}{0.015} \\
\hline & SSI & $56(14.8)$ & $322(85.2)$ & $378(69.6)$ & \\
\hline \multirow[t]{2}{*}{ Familyb income } & Insufficient & $8(5.2)$ & $147(94.8)$ & $155(28.5)$ & \multirow{2}{*}{0.001} \\
\hline & Sufficient & $60(15.5)$ & $328(84.5)$ & $388(71.5)$ & \\
\hline \multirow[t]{2}{*}{ Smoking $^{c}$} & Smoker & $6(11.5)$ & $46(88.5)$ & $52(9.6)$ & \multirow{2}{*}{0.822} \\
\hline & Non-smoker & $62(12.6)$ & $429(87.4)$ & $491(90.4)$ & \\
\hline \multirow[t]{2}{*}{ Alcohol Consumption ${ }^{c}$} & Yes & $7(31.8)$ & $15(68.2)$ & $22(4.1)$ & \multirow{2}{*}{0.005} \\
\hline & No & $61(11.7)$ & $460(88.3)$ & $521(95.9)$ & \\
\hline Chronic disease & Yes & $60(12.8)$ & 409 (87.2) & $469(86.4)$ & \\
\hline & No & $8(10.8)$ & $66(89.2)$ & $74(13.6)$ & 0.032 \\
\hline Total & $68^{d}(12.5)$ & $475(87.5)$ & $543(100.0)$ & & \\
\hline
\end{tabular}

(Age range of participants: 65-95 years; average age: $72.9 \pm 6.5$ years)

* having received one, two or all three of the mentioned vaccinations; a, whether subjects received information about vaccination by a healthcare provider or a doctor; SSI, Social Security Institution; b, income perceived by subject; $c$, whether or not smoking or alcohol habits continue, regardless of the previous situation; $d$, In total, 63 subjects received influenza vaccination only, 3 received both influenza and pneumococcal vaccinations, 1 received pneumococcal vaccination and 1 received all three vaccinations. As a result, 68 subjects received at least one vaccination. 
Table 2. Subjects indicating that they have only heard about a particular vaccination before.

\begin{tabular}{|l|r|r|r|}
\hline \multirow{2}{*}{ Vaccination } & Have heard about vaccination & Have not heard about vaccination & \multirow{2}{*}{ Total } \\
\cline { 2 - 5 } & Number (\%) & Number (\%) & \\
\hline Influenza & $286(52.7)$ & $257(47.3)$ & $543(100.0)$ \\
\hline Pneumococcal & $146(26.9)$ & $397(73.1)$ & $543(100.0)$ \\
\hline Herpes zoster & $36(6.6)$ & $507(93.4)$ & $543(100.0)$ \\
\hline
\end{tabular}

Table 3. The results of binary logistic regression analysis containing factors affecting influenza, pneumococcal and herpes zoster vaccination among people aged 65 years and older.

\begin{tabular}{|c|c|c|c|c|c|c|c|}
\hline $\begin{array}{l}\text { Independent } \\
\text { variables }\end{array}$ & & B & S.E & Wald & $\begin{array}{l}\text { Odds } \\
\text { Ratio }\end{array}$ & $\begin{array}{r}95 \% \\
\begin{array}{r}\text { Confidence } \\
\text { Interval }\end{array} \\
\end{array}$ & $p$ \\
\hline \multirow{2}{*}{$\begin{array}{l}\text { Vaccination } \\
\text { information } \\
\text { provided }\end{array}$} & No & 1.888 & 0.414 & 20.787 & 6.6 & \multirow[t]{2}{*}{$2.9-14.9$} & \multirow[t]{2}{*}{0.001} \\
\hline & Yes & & & & Reference & & \\
\hline \multirow{2}{*}{$\begin{array}{l}\text { Elementary } \\
\text { school and } \\
\text { higher }\end{array}$} & No & 0.963 & 0.278 & 11.966 & 2.6 & \multirow[t]{2}{*}{$1.5-4.5$} & \multirow[t]{2}{*}{0.001} \\
\hline & Yes & & & & Reference & & \\
\hline \multirow{2}{*}{$\begin{array}{l}\text { Family } \\
\text { income* }\end{array}$} & Insufficient & 0.987 & 0.400 & 6.083 & 2.7 & \multirow[t]{2}{*}{$1.2-5.9$} & \multirow[t]{2}{*}{0.006} \\
\hline & Sufficient & & & & Reference & & \\
\hline \multirow{2}{*}{$\begin{array}{l}\text { Place of } \\
\text { residence }\end{array}$} & Village/suburb & 0.770 & 0.283 & 7.424 & 2.2 & \multirow[t]{2}{*}{$1.2-3.7$} & \multirow[t]{2}{*}{0.006} \\
\hline & City/town & & & & Reference & & \\
\hline
\end{tabular}

* income perceived by individual

Table 4. Percentage and reasons of subjects indicating that they will not undergo vaccination when their doctor advises influenza, pneumococcal and herpes zoster vaccinations.

\begin{tabular}{|l|r|}
\hline \multicolumn{1}{|c|}{ I will not get vaccinated } & Number (\%) \\
\hline Response & $34 / 543(6.3)$ \\
\hline Fear of side effects & $30 / 543(5.5)$ \\
\hline I do not think it is necessary because I am healthy & $13 / 543(2.4)$ \\
\hline I do not think it is necessary because I am old & $5 / 543(0.9)$ \\
\hline No idea & $\mathbf{8 2 / 5 4 3 ( 1 5 . 1 )}$ \\
\hline Total number (\%) & \\
\hline
\end{tabular}




\section{DISCUSSION}

Similar to that reported in previous studies, the vaccination rates amongst the elderly for the three vaccines investigated in the present study in the study area was $12.5 \%$, and this rate is insufficient (1416). The lack of knowledge regarding the vaccine, lack of primary education, low income level and living in villages and rural areas were determined as factors affecting this situation.

In Europe, the highest rate of influenza vaccination in the elderly was achieved in the Netherlands with a percentage of $77 \%$, and the lowest rate was in Estonia with a percentage of $1 \%$ (10). In the western part of Turkey, the influenza vaccination rate in the population was $15 \%(14)$, whereas that in the present study was $12.3 \%$. Influenza is one of the leading causes of vaccinepreventable infections. A recent study in Taiwan found that the rates of pneumonia and acute coronary syndromes were lower in individuals immunised for influenza in locations with high air pollution during the winter season, and patients who were vaccinated against influenza were less affected on days when the air temperature decreased (17). In an extensive study, it was found that influenza vaccination during influenza seasons between 2000 and 2009 not only reduced mortality rates but also reduced hospitalisation rates (18). In the present study, when participants (patients aged $\geq 65$ years) were asked about pneumococcal vaccine, $26.9 \%$ of the participants stated that they had previously heard of this vaccine.

The Community-Acquired Pneumonia Immunization Trial in Adults study demonstrated the efficacy of PCV13, and another study found that $38 \%$ of invasive pneumococcal diseases was caused by the serotypes that could be prevented by PPSV23 administration $(19,20)$. In Scotland during the 2003/2004 winter season, PPSV23 was found to reduce the risk of invasive pneumococcal disease in the elderly by one-third, and similarly, a study investigating a large number of the elderly in Sweden found that influenza and 23-valent pneumococcal vaccination significantly reduced both influenza infection and invasive pneumococcal disease $(8,21)$.

Furthermore, $68 \%$ of patients suffering from $\mathrm{HZ}$ and its complications are aged 50 years and older. When postherpetic neuralgia develops, it may impair social activity and sleep patterns of the person by causing pain that lasts for months or even years that does not respond well to analgesics. In addition, it may cause various ophthalmologic complications and zoster meningitis $(6,11)$.

Oxman et al. found that the efficacy of $\mathrm{HZ}$ vaccine is $51 \%$ against $\mathrm{HZ}$ infection and $67 \%$ against postherpetic neuralgia (22). In the present study, the percentage of participants who were aware of $\mathrm{HZ}$ vaccination was $6.6 \%(36 / 543)$, and the vaccination rate was only $0.2 \%(1 / 543)$. In a large-scale cohort study conducted by Langan et al., the rates of $\mathrm{HZ}$ vaccination were $2.5 \%$ and $1.5 \%$ in the age groups of 65-79 years and $\geq 80$ years, respectively, and this rate was $0.3 \%$ in African Americans (12). In this study, it was found that $5.5 \%$ of participants (30/543) were previously provided with information on any of the vaccines, and $46.7 \%$ of previously informed participants received at least one vaccine of influenza, pneumococcal or $\mathrm{HZ}$ vaccines.

A study conducted in the United States found that family physicians and internists remain unclear regarding the importance of vaccination (16). Similar to our results, Schneeberg et al. in Canada found that $16.7 \%$ of those who were not informed of pneumococcal vaccination by a physician or healthcare provider were vaccinated, whereas $79.8 \%$ of informed patients were vaccinated (23).

These findings indicate that the knowledge of vaccination affects vaccination rates. In immunisation of the elderly, healthcare providers must initially insist on emphasising the importance of each of these vaccinations. In our study, $84.9 \%$ of the participants indicated that they would 
receive vaccination if the doctor advises (Table 4), demonstrating the power of healthcare providers in persuading them for vaccination $(14,23)$.

In the logistic regression analysis of the data, the number of unvaccinated subjects was 2.6 times higher in those with low educational level. In this study, the vaccination rate amongst participants with 'primary and higher education' was 20.2\%, whereas this rate was $8.3 \%$ amongst participants with insufficient education $(p=0.001)$. In the aforementioned study, influenza vaccination rate was found to be 3.2 times lower amongst those without primary education (14). In the abovementioned Canadian study, the rate of people who did not receive pneumococcal vaccine was 1.6 times higher in elderly with primary/secondary education compared with those with university education (23).

When the effect of income level on vaccination status was analysed, it was found that the rate of subjects who did not receive influenza, pneuomococcal or $\mathrm{HZ}$ vaccines was 2.7 times higher in participants with insufficient income compared with those with sufficient income (Table 3).

In a study conducted on 2,000 people in Pakistan, pneumococcal vaccination rate amongst people in lower socioeconomic classes was $2.3 \%$, whereas this rate was $16.5 \%$ amongst people in higher socioeconomic classes (24). In the abovementioned cohort study, $\mathrm{HZ}$ vaccination rate in individuals with low income was $0.6 \%$, whereas it was $2.6 \%$ in those with high income (12).

In this study, the rate of unvaccinated participants living in villages and suburbs was 2.2 times higher than the rate in participants living in cities and town centres (Table 3). This finding may indicate that people living in the villages are in higher need of education. In this study, the rate of participants indicating that they 'would not get vaccinated' for all three vaccinations on the doctor's recommendation vaccination was $15.1 \%$. When we looked at the distribution, we found that the proportion of participants who would not get vaccinated due to the fear of side effects was 34/82, and they had concerns regarding vaccination. In one of the previous studies, it was found that $58 \%$ of people believed that pneumococcal vaccination would protect against the disease, but they were concerned about the side effects of vaccination (25).

Although awareness of influenza vaccine has increased due to outbreaks in recent years, awareness of the other vaccines is low, and the level of awareness appears to be related to the socioeconomic levels of individuals (24). Low level of awareness of $\mathrm{HZ}$ vaccine compared with influenza and pneumococcal vaccines may be due to insufficient information by doctors, relatively high price of $\mathrm{HZ}$ vaccine and less appearance on social media platforms such as television and the Internet.

In conclusion, the rate of vaccination against influenza, pneumococcal disease and $\mathrm{HZ}$ in elderly was found to be low. The level of pneumococcal and especially $\mathrm{HZ}$ vaccination is very low compared with that of influenza. The lacks of knowledge in the elderly, low educational level, insufficient income and living in villages and suburbs have an impact on the low vaccination rate for all three diseases. Independent of these factors, the majority of participants have stated that they would get vaccinated if the physician advises. In light of this information, healthcare providers and physicians should inform the elderly about vaccinations and recommend vaccination. In addition, although $\mathrm{HZ}$ is not as common as other diseases, the importance of $\mathrm{HZ}$ vaccination should not be overlooked because it may cause neurological pain and other serious complications in the elderly.

\section{Conflicts of interest}

The authors declare that there are no conflicts of interest. 


\section{REFERENCES}

1. World Health Organization. Ageing and health: Fact sheet. [Internet] Available from: http://www.who.int/ news-room/fact-sheets/detail/ageing-and-health. Accessed: 05.08.2018.

2. Turkish Statistical Institute. Main statistics results of 2017: population and demography, population statistics. [Internet] Available from: http://www. turkstat.gov.tr/Start.do. Accessed: 05.08.2018.

3. Montecino-Rodriguez E, Berent-Maoz B, Dorshkind K. Causes, consequences, and reversal of immune system aging. J Clin Invest 2013;123(3):958-65. (PMID:23454758).

4. Weinberger $B$, Herndler-Brandstetter D, Schwanninger A, Weiskopf D, Grubeck-Loebenstein B. Biology of immune responses to vaccines in elderly persons. Clin Infect Dis 2008;46(7):1078-84. (PMID:18444828).

5. Weinberger B, Grubeck-Loebenstein B. Vaccines for the elderly. Clin Microbiol Infect 2012 Suppl;18(5):100-8. (PMID:22862783).

6. Lang PO, Aspinall R. Vaccination in the elderly: what can be recommended? Drugs Aging 2014;31(8):58199. (PMID:24928553).

7. Ludwig E, Bonanni P, Rohde G, Sayiner A, Torres A. The remaining challenges of pneumococcal disease in adults. Eur Respir Rev 2012;21(123):57-65. (PMID:22379175).

8. Mooney JD, Weir A, McMenamin J, et al. The impact and effectiveness of pneumococcal vaccination in Scotland for those aged 65 and over during winter 2003/2004. BMC Infect Dis 2008;8(1):53. (PMID:18433473).

9. CDC. Recommended immunizations for adults: by age. 2018. [Internet] Available from: https://www.cdc. gov/vaccines/schedules/downloads/adult/adultschedule-easy-read.pdf. Accessed: 05.08.2018.

10. Triglav TK, Poljak M. Vaccination indications and limits in the elderly. Acta Derm-Venereol 2013;22(3):65-70. (PMID:24089135).

11. Yawn BP, Saddier P, Wollan PC, Sauver JLS, Kurland MJ, Sy LS. A population-based study of the incidence and complication rates of herpes zoster before zoster vaccine introduction. Mayo Clin Proc 2007;82(11):1341-9. (PMID:17976353).

12. Langan SM, Smeeth L, Margolis DJ, Thomas SL. Herpes zoster vaccine effectiveness against incident herpes zoster and post-herpetic neuralgia in an older US population: a cohort study. PLoS med 2013;10(4):e1001420. (PMID:23585738).

13. Köse MR. Utilization of Health Care Services (Chapter 8). In: MR Köse, BB Başara, C Güler et al. (Eds). Republic of Turkey Ministry of Health: Health Statistics Yearbook 2015, General directorate of health research. Ankara 2016, pp 134-40. [Internet] Available from: http://ekutuphane.sagem.gov. tr/kitaplar/health_statistics_yearbook_2015.pdf. Accessed: 06.08.2018.

14. Polat HH, Öncel S, Turhan Ö, Akcan A, Eravşar $K$, Yalcin AN. Influenza vaccination in 65 and over age adults in Antalya/Turkey. Turk J Geriatr 2012;15(4):371-7 (in Turkish).

15. Lang PO. Why influenza viruses continue to pose a significant threat to aging and aged populations worldwide. Curr Geriatr Rep 2014;3(1):56-65.

16. Hurley LP, Bridges CB, Harpaz R, et al. Physician attitudes toward adult vaccines and other preventive practices, United States, 2012. Public Health Reports 2016;131(2):320-30. (PMID:26957667).

17. Huang $\mathrm{CH}$, Chao DY, Wu CC, et al. Influenza vaccination and the endurance against air pollution among elderly with acute coronary syndrome. Vaccine 2016;34(50):6316-22. (PMID:27823899).

18. Wong K, Campitelli MA, Stukel TA, Kwong JC. Estimating influenza vaccine effectiveness in community-dwelling elderly patients using the instrumental variable analysis method. Arch Intern Med 2012;172(6):484-91. (PMID:22371873).

19. Webber C, Patton M, Patterson S, Schmoele-Thoma B, Huijts SM, Bonten MJ. Exploratory efficacy endpoints in the community-acquired pneumonia immunization trial in adults (CAPiTA). Vaccine 2017;35(9):1266-72. (PMID:28173960).

20. Chiou WY, Lee MS, Hung SK, et al. Effectiveness of 23-valent pneumococcal polysaccharide vaccine on elderly long-term cancer survivors: a populationbased propensity score matched cohort study. BMJ open 2018;8(5):e019364. (PMID:29769253).

21. Hedlund J, Christenson B, Lundbergh P, Örtqvist A. Effects of a large-scale intervention with influenza and 23-valent pneumococcal vaccines in elderly people: a 1-year follow-up. Vaccine 2003;21(2526):3906-11. (PMID:12922125).

22. Oxman MN, Levin MJ, Johnson GR, et al. Shingles Prevention Study Group. A vaccine to prevent herpes 
zoster and postherpetic neuralgia in older adults. N Engl J Med 2005;352(22):2271-84. (PMID:15930418).

23. Schneeberg A, Bettinger JA, McNeil S, et al. Knowledge, attitudes, beliefs and behaviours of older adults about pneumococcal immunization, a Public Health Agency of Canada/Canadian Institutes of Health Research Influenza Research Network (PCIRN) investigation. BMC Public Health 2014;14(1):442. (PMID:24884433).

24. Baig SA, Hassan M, Ahmed SM, Moazzam W, Inayat A. A cross-sectional study to investigate pneumococcal vaccination in the elderly in a low income county: patient knowledge, awareness, and attitudes of vaccination and prevalence rates by socioeconomic status. Hum Vaccin Immunother 2014;10(4):1024-7. (PMID:24495898).

25. Shijun L, Erping $X$, Yan $L$, et al. Factors associated with pneumococcal vaccination among an urban elderly population in China. Hum Vaccin Immunother 2014;10(10):2994-9. (PMID:25483646).

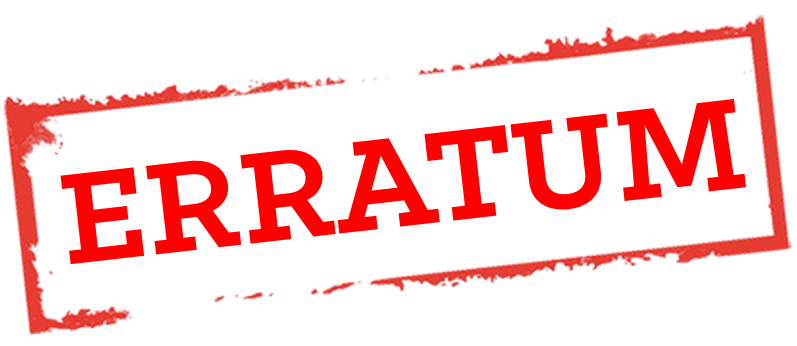

The authors and institutions of the article titled "DEATH ANXIETY IN THE ELDERLY: RELATION TO PARTICIPATION IN DAILY LIFE" (TJG 2018;21(3):383-93. DOI:10.31086/tjgeri.2018344053) should be as follows:

Şeyda DÜLGERLER-Ege University, Faculty of Nursing, Department of Psychiatry, İzmir-Turkey

Gülseren KESKIN- Ege University, Atatürk Medical Vocational Training School, Department of Psychiatry, İzmir-Turkey

Esra ENGIN-Ege University, Faculty of Nursing, Department of Psychiatry, İzmir-Turkey

Serap ÖZER- Ege University, Faculty of Nursing, Department of Internal Medicine, İzmir-Turkey

Ayşegül BiLGE- Ege University, Faculty of Nursing, Department of Psychiatry, İzmir-Turkey

Sevgi PEKER- Ege University, Faculty of Nursing, İzmir-Turkey 